\title{
A Comparative Study of Dietary Intake and Expenditure of Urban and Rural Adolescent Girls age 15-16 years
}

\author{
Narinder Kaur, Ashok Kumar and Vishal Kumar
}

\begin{abstract}
Aim: A comparative study of dietary intake and expenditure of urban and rural adolescent girls age 15-16 years. Material \& Methods: The study was conducted on 60 urban (age 16.09 \pm 0.62 years) and 60 rural (age 15.86 \pm 0.60 years) adolescent girls. All subjects were taken from district Sangrur (Punjab). DINE healthy software, version (1994-1997 dine healthy system was used for the dietary analysis of food consumed by the subjects. Through this software nutrient intake and energy expenditure was calculated. Three days recall method was used to determine caloric intake and all activities with duration done by subjects for 24 hour were recorded for energy expenditure. Results: Dietary intake of urban and rural girls was $2324.28 \pm 192.11 \mathrm{kcal}$ and $2366.93 \pm 221.69 \mathrm{kcal}$ respectively. Energy expenditure of urban girls was $2451.63 \pm 165.93 \mathrm{kcal}$ and rural girls were $2599.37 \pm 144.95 \mathrm{kcal}$. Conclusion: The results showed that the urban and rural girls were taking sufficient dietary intake. But urban girls' energy expenditure was below than the rural girls. Both urban and rural adolescent girls were taking extra energy from fat that was 46 per cent and 46.77 per cent respectively.
\end{abstract}

Narinder Kaur

Ph.D. Research Scholar, Department of Sports

Science, Punjabi University Patiala (Punjab)

India

Ashok Kumar

Associate Professor, Department of Sports

Science, Punjabi University Patiala (Punjab)

India

Email: akashokin@gmail.com

\section{Vishal Kumar}

Ph.D. Research Scholar, Department of Sports

Science, Punjabi University Patiala (Punjab)

India

E-mail:vishalkandiara@yahoo.com

\section{Introduction}

World Health Organization defines adolescence as the segment of life between the ages of 10-19 years. Adolescence is a transitional stage of life development through which a child becomes an adult. At this stage the bodies of an adolescent girl are not like a child anymore but are also not quite yet adult bodies. Balanced nutrition is utmost important in these young adult's life. For females required a diet consist of food, vegetables, whole grains, lean meats and low-fat dairy for strong bones and prevention of osteoporosis later in life calcium is required. India is in state of nutritional transition, where urbanization has contributed to shift in diet and obesity is on rise with micronutrients deficiency and protein energy malnutrition continues to be present. Under nutrition among early 


\section{Journal of Exercise Science \& Physiotherapy, Vol. 12, No. 2, 2016 ISSN: 0973-2020 (Print) \\ ISSN: 2454-6089 (Online)}

adolescent girls of rural areas in India is a major health problem (Maiti et al., 2011).Adolescents need additional nourishing diet as the foundation for lifetime in health; strength and intellectual validity is laid during this period of age (Kapil et al., 1993). Dietary intake is a product of many variables like family income and family size, socio-economic status, mother's occupational, father's occupation and knowledge of sound nutritional practices which would ultimately affect the physical growth (Tamilsari and Sasirekha 1990, Cole et al., 1997). Adolescents are unaware of the foods essential for good health, eat very few of the food which supply the basic nutrients (Thomas and Call 1973). Meal skipping greater use of fast foods and fad diets contribute to poor dietary intake among young people (Jakobivitis et al., 1977). Most of the children eat improperly. Only 83.2 per cent have their breakfast regular and 62.6 per cent have regular light lunch. Rural children have consumed 34.9 per cent sweets but fruits and vegetables in low quantity. Eating habits may depend on parent's education and household situations (Kollataj et al., 2011).

\section{Material \& Methods}

An attempt has been made to study the Dietary analysis of 120 urban and rural adolescent girls. The subjects were divided into urban and rural groups on the basis of their residence. Each group was comprised of 60 girls. All the subjects were ranging in age 1516 years. Various parameters measured in the present study on urban and rural girls have been enlisted follow:

I. General Physical Characteristics

I. Dietary Intake and Energy Expenditure
1. Age (years)

2. Height (cms)

3. Weight (kgs)

4. BMI $\left(\mathrm{kg} / \mathrm{m}^{2}\right)$

- Nutrient intake-Major nutrients:

- Daily dietary intake of carbohydrates

- Daily dietary intake of fats

- Daily dietary intake of proteins

- Energy Intake (EI)

- Energy Expenditure (EE)

To determining the caloric intake, a three days recall method was used that is during three days everything eaten and drunk along with the specific amount eaten by the subject was recorded. All activities of the subject completed in 24 hours was recorded with duration of activity and category of activity. DINE healthy software, version (O1994-1997 dine system was used for the dietary analysis of food consumed by the subject. With the help of this software nutrient intake and energy expenditure of the subjects was calculated. 
Journal of Exercise Science \& Physiotherapy, Vol. 12, No. 2, 2016

ISSN: 0973-2020 (Print)

ISSN: 2454-6089 (Online)

Results and Discussions

Table 1. Mean SD of Dietary Intake \& Expenditure of Urban Adolescent Girls

\begin{tabular}{|c|c|c|c|}
\hline Variables & Mean & S.D. & $\begin{array}{l}\text { dietary } \\
\text { intake \% }\end{array}$ \\
\hline Age (years) & 16.09 & 0.62 & \\
\hline Height (cms) & 153.1 & 6.71 & \\
\hline Weight (kgs) & 44.47 & 8.12 & \\
\hline BMI $\left(\mathrm{kg} / \mathrm{m}^{2}\right)$ & 18.97 & 2.93 & \\
\hline $\begin{array}{l}\text { Daily dietary intake of } \\
\text { carbohydrates (gm) }\end{array}$ & $\begin{array}{l}1063.09 \\
\text { (Calorie) } \\
266(\text { gm) }\end{array}$ & 33.35 & 45.83 \\
\hline Daily dietary intake of fats (gm) & $\begin{array}{l}1071.46 \\
\text { (Calorie) } \\
118.83 \text { (gm) }\end{array}$ & 17.84 & 46 \\
\hline Daily dietary intake of proteins (gm) & $\begin{array}{l}244.47 \text { (Calorie) } \\
60.96 \text { (gm) }\end{array}$ & 10.10 & 10.10 \\
\hline Energy Intake (EI) (Kcal) & 2324.38 & 192.11 & \\
\hline Energy Expenditure (EE) (Kcal) & 2451.63 & 165.93 & \\
\hline
\end{tabular}

The mean age, height, weight and BMI of urban adolescent girls were $16.09 \pm 0.62$ year, $153.1 \pm 6.71 \mathrm{~cm}, 44.47 \pm 8.12 \mathrm{~kg}$ and $18.97 \pm 2.93 \mathrm{~kg} / \mathrm{m}^{2}$ respectively (Table 1 ). The daily dietary intake of carbohydrates, fats and proteins of urban adolescent girls were $266 \pm 33.35 \mathrm{gm}, 118.83 \pm 17.84 \mathrm{gm}, 60.96 \pm 10.10 \mathrm{gm}$ respectively. The energy intake of urban adolescent Punjabi girls was 2324.38 $\pm 192.11 \mathrm{kcal}$ and energy expenditure was $2451.63 \pm 165.93 \mathrm{kcal}$ (Table 1).

Table 2. Mean SD of Dietary Intake \& Expenditure of Rural Adolescent Girls

\begin{tabular}{|c|c|c|c|}
\hline Variables & Mean & S.D. & $\begin{array}{l}\text { dietary } \\
\text { intake \% }\end{array}$ \\
\hline Age (years) & 15.86 & 0.60 & \\
\hline Height (cms) & 155.2 & 7.14 & \\
\hline Weight (kgs) & 44.25 & 6.51 & \\
\hline BMI $\left(\mathbf{k g} / \mathbf{m}^{2}\right)$ & 18.39 & 2.62 & \\
\hline $\begin{array}{l}\text { Daily dietary intake of } \\
\text { carbohydrates (gm) }\end{array}$ & $\begin{array}{l}\text { 1063.48(Calorie) } \\
266.17 \text { (gm) }\end{array}$ & 37.48 & 45.15 \\
\hline Daily dietary intake of fats (gm) & $\begin{array}{l}\text { 1112.72(Calorie) } \\
123.47(\mathrm{gm})\end{array}$ & 23.59 & 46.77 \\
\hline $\begin{array}{l}\text { Daily dietary intake of proteins } \\
\text { (gm) }\end{array}$ & $\begin{array}{l}246.21 \text { (Calorie) } \\
62.26(\mathrm{gm})\end{array}$ & 12.80 & 10.41 \\
\hline Energy Intake (EI) (Kcal) & 2366.93 & 221.69 & \\
\hline Energy Expenditure (EE) (Kcal) & 2599.37 & 144.95 & \\
\hline
\end{tabular}

The mean age, height, weight and BMI of rural adolescent girls were 15.86 \pm 0.60 year, $155.2 \pm 7.14 \mathrm{~cm}, 44.25 \pm 6.51 \mathrm{~kg}$ and $18.39 \pm 2.62 \mathrm{~kg} / \mathrm{m}^{2}$ respectively (Table 1 ). The daily 


\section{Journal of Exercise Science \& Physiotherapy, Vol. 12, No. 2, 2016 \\ ISSN: 0973-2020 (Print) \\ ISSN: 2454-6089 (Online)}

dietary intake of carbohydrates, fats and proteins of rural adolescent girls were 266.17 $\pm 37.48 \mathrm{gm}, 123.47 \pm 17.823 .594 \mathrm{gm}, 62.26 \pm 12.80 \mathrm{gm}$ respectively. The energy intake of rural adolescent Punjabi girls was $2366.93 \pm 221.69 \mathrm{kcal}$ and energy expenditure was $2599.37 \pm 144.95 \mathrm{kcal}$ (Table 2).

\section{Discussion}

Furthermore, both groups of adolescent girls also put on display statistically insignificant difference in percent contribution of carbohydrates, fats and protein and in total energy intake. Rural girls displayed more energy expenditure than urban girls. It has been explored from the above-mentioned review of literature that most of the countries of the world are experiencing deterioration in nutritional of their young generation. Therefore, the results of the present study will also be helpful in providing the information regarding nutritional status of rural and urban Punjabi adolescent girls.

\section{Acknowledgment}

Thank to all the subjects who were voluntarily participated in this study.

\section{Conclusion}

The results showed that the urban and rural girls were taking sufficient dietary intake. But urban girls' energy expenditure was below than the rural girls. Both urban and rural adolescent girls were taking extra energy from fat that was 46 per cent and 46.77 per cent respectively.

\section{References}

Cole, A.H., Taiwoo, O., Nuragbara, and Cole, C.E. (1997) Energy intake, anthropometry and composition of Nigerian adolescent girls: A case study of an institutionalized secondary school in Ibadan. Br.J. Nutr.77:495-509.

Dine system, Inc. (1997) National Institute of Health, Public Health Service and Department of Health and Human Services Nee York, USA.

Jakobivits, C.; Halstead, P.; Kelley,L.; Roe, D.A. and Young, C.M. (1977) Eating habits and nutrient intake of college women over a thirty year period. Am.J. Dietet.Association.71:405-411.

Kapil, U.; Manocha, S. and Bhasin, S. (1993) Dietary intake amongst well to do adolescent boys and girls in Delhi. Paediat,30:1017-1021.

Kołłątaj W, Sygit K, Sygit M, Karwat ID, Kołłątaj B. (2011) Eating habits of children and adolescents from rural regions depending on gender, education, and economic status of parents. Ann Agric Environ Med.18(2):393-7.

Maiti S, KM Ali,D De, TK Bera, D Ghosh, S Paul (2011)A Comparative Study on Nutritional Status of Urban and Rural Early Adolescent School Girls of West Bengal, India. Journal of Nepal Paediatric Society, Vol 31, No 3.

Tamilsari,P. and Sasirekha, N.S. (1990) Body weight, diet, serum cholesterol level in selected obese girls. Ind.J.Nutr.Dietet.27:35-38.

Thomas, J.A. and call, D.L. (1973) Eating between meals- A nutritional probem among teenagers. Nutr.Rev.31:137-139.

\section{Conflict of Interest: None Declared}

